\title{
Epimacular brachytherapy — old ghost or new age?
}

\author{
Norbert Bornfeld
}

Received: 25 January 2011 / Accepted: 25 January 2011 /Published online: 20 February 2011

(C) Springer-Verlag 2011

Treatment of neovascular age-related macular degeneration (AMD) has reached a new level with the advent of intravitreal VEGF inhibitors. Today VEGF inhibitors are the treatment of choice [1]. Nevertheless, repetitive injections generating considerable costs are required. Among possible alternatives or adjuvant treatments, radiation therapy enjoys a revival of interest. However, while the VIDION system for epimacular brachytherapy gains increasing popularity even in the lay press, it is important to understand the physical and pathophysiological properties of radiotherapy for $\mathrm{AMD}$, and to rank it within the spectrum of the evidence-based therapies for neovascular AMD.

Radiation therapy in AMD is supposed to selectively inhibit proliferation of growing (endothelial) cells while sparing the repair mechanisms of slowly growing cells [2]. Additional effects such as inhibition of cells producing proangiogenic factors and cells involved in scar formation are possible. Radiation therapy is known to be successful for intraocular vascular tumors (choroidal cavernous hemangioma) [3], and synergistic effects of VEGF inhibitors and radiation therapy compared to radiation alone were demonstrated in experimental studies in tumor biology [4].

As in radiotherapy of tumors, radiation for AMD can be applied either as teletherapy or brachytherapy. The first pilot study investigating the effectiveness of external beam radiotherapy in noevascular AMD was published in 1993 by Chakravathy and coauthors [5], using a photon beam delivering a target volume dose of 10-15 Gy in 16 patients.

\section{N. Bornfeld $(\square)$}

Zentrum für Augenheilkunde, Universitätsklinikum Essen,

Hufelandstrasse 55,

45122 Essen, Germany

e-mail: nbornfeld@googlemail.com
Since this study, several studies were published using a linear accelerator, stereotactic radiation from different sources, proton beam irradiation [6], as well as the newly developed microcollimated megavolt therapy [7]. Brachytherapy can be applied using either episcleral [8,9] or epiretinal applicators via a pars plana approach [10].

After the initial publication by Charkavarthy and coworkers [5], several studies were published on external beam radiotherapy including randomised clinical trials (RAD study [2] and SFRADS study [11]). None of these studies, as well as a recently published COCHRANE report [6], was able to demonstrate a benefit of radiation therapy in the treatment of exudative AMD.

Brachytherapy has the benefit of avoiding radiation of tissue outside the target volume. Episcleral brachytherapy for AMD was performed using strontium $\left({ }^{90} \mathrm{Sr} /{ }^{90} \mathrm{Y}\right)$ or palladium plaques $\left({ }^{103} \mathrm{~Pa}\right) \cdot{ }^{103} \mathrm{~Pa}$ is a (bitte griechisches gamma einsetzen)-emitter with a photon energy of $21 \mathrm{kV}$ (compared to $28 \mathrm{kV}$ for ${ }^{125} \mathrm{I}$ ) with a lower tissue penetration compared to ${ }^{125} \mathrm{I}$. Long-term results with a ${ }^{103} \mathrm{~Pa}$ plaque were able to demonstrate a reduction of the exudation but no improvement in function [8]. ${ }^{90} \mathrm{Sr}$ is a $\beta$-emitter with a decay energy of $0.55 \mathrm{MeV}$ and a half life of 27.78 years that decays to ${ }^{90} \mathrm{Y}$ with a decay energy of $2.27 \mathrm{MeV}$. The tissue penetration depth is limited due to a steep dose fall-off which allows a localized radiation therapy of a very small volume. The $50 \%$ isodose of strontium plaques in tissue is $1 \mathrm{~mm}$ [12]. In contrast to encouraging preliminary results, episcleral strontium brachytherapy for choroidal neovascularisation had no advantages compared to the natural course in long-term studies [9].

The VIDION system of NeoVista Inc. is an afterloading system using ${ }^{90} \mathrm{Sr} /{ }^{90} \mathrm{Y}$ for irradiation of the macula. After a 3-port pars plana vitrectomy, the strontium source is forwarded through a hand-held applicator for macular 
irradiation until a target volume dose of 24 Gray is reached after 4 minutes [10]. Considering the steep dose fall-off, an extreme exact positioning (for a fraction of a millimeter) of the source is required to prevent large deviations from the 24 Gy target dose. As the target tissue is the choroid, the epiretinal placement of the probe results in a (presumably) unwanted higher dose in the retina compared to the underlying choroid.

So far, only phase I/II studies for epiretinal brachytherapy in AMD using the VIDION system have been published $[13,14]$. While the first study demonstrated that a minimum dose of 24 Gy is required to achieve a therapeutic effect [14], the other study demonstrated the effect of brachytherapy combined with two injections of bevacizumab [13]. Radiation-induced complications were not reported, and the average increase in visual acuity was 8.9 letters. The phase III study CABERNET included more than 450 patients since October 2009 to compare intravitreal injections with ranibizumab with the epiretinal brachytherapy using the VIDION system followed by two injections of ranibizumab injections 1 month apart thereafter (clinicaltrials.gov NCT00454389). To date, no data from this study have been published, and the study design may not allow to identify the effect of brachytherapy alone, as intravitreal injections are used in both arms.

An advantage of the VIDION system is the exact localization of the radiation. Disadvantages are the unfavourable dose distribution with respect to the target volume (subfoveal choroid), and in particular the high dose rate used when delivering the target volume dose in a single fraction. Longterm complications such as optic neuropathy and radiation retinopathy are dreaded complications of radiation therapy to the eye and orbit which appear with a variable latency of up to several years [15]. Considering the conversion factors for the relative biological efficacy of high-dose rate radiation [16], the required target dose of 24 Gy may exceed the threshold of radiation maculopathy. Further disadvantage of the VIDION system is owed to the fact that the irradiation is delivered during a complete vitrectomy, and to the associated risks linked to posterior vitreous detachment and more importantly to the development of a nuclear cataract that requires surgery.

New aspects with regard to radiation therapy of neovascular AMD could include the development of a microcollimated system for external beam radiotherapy (OrayaSystem). The microcollimated megavolt therapy (Oraya Therapeutics, USA) consists of three microcollimated $100 \mathrm{kV}$ beams directed via pars plana into the eye, crossing in the macular area. This allows sparing of the anterior segment while achieving an optimal dose distribution in the macular area [17]. So far, only results from experimental studies and a phase I study are available [18]. Theoretically, an excellent dose distribution can be achieved; however, the same thoughts as above apply regarding the effectiveness of irradiation for the treatment of choroidal neovascular disease and its side-effects.

When taking the currently available data into consideration, both systems should be only used in clinical trials. As the effect of radiotherapy in AMD may be the enhanced efficacy of intravitreal anti-VEGF treatment, the current trials like the CABERNET study may be unable to answer this question. A more effective trial could be to investigate brachytherapy vs PRN injections of ranibizumab after an initial loading dose. When radiation therapy can improve the efficacy of intravitreal therapies, the microcollimated system for non-invasive therapy seems more advantageous, offering a favourable dose distribution and avoiding the risks of invasive surgery and - from the data available might be cheaper than the VIDION system.

\section{References}

1. Liew G, Mitchell P (2007) Ranibizumab for neovascular agerelated macular degeneration. N Engl J Med 356:747-748

2. Radiation Therapy for Age-Related Macular Degeneration (RAD) Study Group (1999) A prospective, randomized, double-masked trial on radiation therapy for neovascular age-related macular degeneration. Ophthalmology 106:2239-2247

3. Schilling H, Sauerwein W, Lommatzsch A, Friedrichs W, Brylak S, Bornfeld N, Wessing A (1997) Long-term results after low dose ocular irradiation for choroidal haemangiomas. Br J Ophthalmol 81:267-273

4. Timke C, Zieher H, Roth A, Hauser K, Lipson KE, Weber KJ, Debus J, Abdollahi A, Huber PE (2008) Combination of vascular endothelial growth factor receptor/platelet-derived growth factor receptor inhibition markedly improves radiation tumor therapy. Clin Cancer Res 14:2210-2219

5. Chakravarthy U, Houston RF, Archer DB (1993) Treatment of age-related subfoveal neovascular membranes by teletherapy: a pilot study. Br J Ophthalmol 77:265-273

6. Evans JR, Sivagnanavel V, Chong V (2010) Radiotherapy for neovascular age-related macular degeneration. Cochrane Database Syst Rev 5:CD004004. doi:10.1002/14651858.CD004004. pub3

7. Hanlon J, Lee C, Chell E, Gertner M, Hansen S, Howell RW, Bolch WE (2009) Kilovoltage stereotactic radiosurgery for agerelated macular degeneration: assessment of optic nerve dose and patient effective dose. Med Phys 36:3671-3681

8. Finger PT, Gelman YP, Berson AM, Szechter A (2003) Palladium-103 plaque radiation therapy for macular degeneration: results of a 7 year study. Br J Ophthalmol 87:1497-1503

9. Jaakkola A, Heikkonen J, Tommila P, Laatikainen L, Immonen I (2005) Strontium plaque brachytherapy for exudative age-related macular degeneration: three-year results of a randomized study. Ophthalmology 112:567-573

10. Holmes SM, Micka JA, DeWerd LA (2009) Investigation of a $90 \mathrm{Sr} / 90 \mathrm{Y}$ source for intra-ocular treatment of wet age-related macular degeneration. Med Phys 36:4370-4378

11. Hart PM, Chakravarthy U, Mackenzie G, Chisholm IH, Bird AC, Stevenson MR, Owens SL, Hall V, Houston RF, McCulloch DW, Plowman N (2002) Visual outcomes in the subfoveal radiotherapy 
study: a randomized controlled trial of teletherapy for age-related macular degeneration. Arch Ophthalmol 120:1029-1038

12. Hokkanen J, Heikkonen J, Holmberg P (1997) Theoretical calculations of dose distributions for beta-ray eye applicators. Med Phys 24:211-213

13. Avila MP, Farah ME, Santos A, Duprat JP, Woodward BW, Nau J (2009) Twelve-month short-term safety and visual-acuity results from a multicentre prospective study of epiretinal strontium-90 brachytherapy with bevacizumab for the treatment of subfoveal choroidal neovascularisation secondary to age-related macular degeneration. Br J Ophthalmol 93:305-309

14. Avila MP, Farah ME, Santos A, Kapran Z, Duprat JP, Woodward BW, Nau J (2009) Twelve-month safety and visual acuity results from a feasibility study of intraocular, epiretinal radiation therapy for the treatment of subfoveal CNV secondary to AMD. Retina 29:157-169

15. Archer DB, Gardiner TA (1994) Ionizing radiation and the retina. Curr Opin Ophthalmol 5:59-65

16. Logani S, Cho AS, Ali BH, Withers HR, McBride WH, Kozlov KL, Hall MO, Lee DA, Straatsma BR (1995) Single-dose compared with fractionated-dose radiation of the OM431 choroidal melanoma cell line. Am J Ophthalmol 120:506-510

17. Gertner M, Chell E, Pan KH, Hansen S, Kaiser PK, Moshfeghi DM (2010) Stereotactic targeting and dose verification for agerelated macular degeneration. Med Phys 37:600-606

18. Moshfeghi DM, Kaiser PK, Gertner M (2011) Stereotactic lowvoltage $\mathrm{x}$-ray irradiation for age-related macular degeneration. $\mathrm{Br}$ J Ophthalmol 95(2):185-188 